\title{
Neurologically asymptomatic cerebral oligometastatic prostate carcinoma metastasis identified on [Ga]Ga-THP-PSMA $\mathrm{PET} / \mathrm{CT}$
}

\author{
M. I. Ross ${ }^{1}$, N. Bird ${ }^{2}$, I. A. Mendichovszky $y^{2,3,4^{*+}}$ (D) and Y. L. Rimmer ${ }^{5+}$
}

\begin{abstract}
Background: Brain metastases from prostate cancer are rare and usually only occur in the context of widespread systemic disease. This is the first case report of a solitary brain oligometastasis, in a neurologically intact prostate cancer patient with no other systemic disease, detected using $\left[{ }^{68} \mathrm{Ga}\right] \mathrm{Ga}-\mathrm{THP}-\mathrm{PSMA}$ PET/CT and only the second one using a PSMA-based radiopharmaceutical.

Case presentation: We report the case of a prostate cancer patient presenting 5 years after robot-assisted laparoscopic prostatectomy with biochemical recurrence, no neurological symptoms, and in the absence of metastatic lesions in the body on conventional imaging. A solitary cerebral metastasis was detected using $\left[{ }^{68} \mathrm{Ga}\right] \mathrm{Ga}-$ THP-PSMA PET/CT, surgically resected, leading to a drop in serum PSA and a good recovery.

Conclusion: In this case, $\left[{ }^{68} \mathrm{Ga}\right] \mathrm{Ga}-\mathrm{THP}-\mathrm{PSMA}$ PET/CT resulted in a major change in clinical management and avoided additional morbidity associated with delayed diagnosis and treatment. This report demonstrates the importance of considering the presence of metastatic disease outside the conventional locations of prostate cancer spread, as well as the importance of ensuring comprehensive $\left[{ }^{68} \mathrm{Ga}\right] \mathrm{Ga}$-PSMA PET/CT coverage from vertex to upper thighs.
\end{abstract}

Keywords: $\left[{ }^{68} \mathrm{Ga}\right] \mathrm{Ga}-T H P-P S M A$, Prostate, Cancer, Carcinoma, Metastasis, Cerebral, Brain, Solitary, PET/CT

\section{Background}

Prostate cancer usually metastasises to the pelvic lymph nodes and axial skeleton. Prostate cancer brain metastases mostly present in the late stages of disease and occur in an estimated $0.63 \%$ of patients [1]. The incidence of brain-only metastases in prostate cancer, in the absence of widespread metastatic disease, has been estimated from large cohorts of patients at $0.0061-0.2 \%$ [1-3].

\footnotetext{
* Correspondence: im391@cam.ac.uk

${ }^{\dagger}$ Mendichovszky IA and Rimmer YL have joint senior authorship.

${ }^{2}$ Department of Nuclear Medicine, Cambridge University Hospitals NHS

Foundation Trust, Cambridge Biomedical Campus, Hills Road, Cambridge CB2 OQQ, UK

${ }^{3}$ Department of Radiology, University of Cambridge, Cambridge Biomedical Campus, Hills Road, Cambridge CB2 0QQ, UK

Full list of author information is available at the end of the article
}

Due to the low incidence of cerebral metastatic disease, cross-sectional neurological imaging is not routinely performed in prostate cancer patients and PET/CTs using PSMA-based radiopharmaceuticals are protocoled to cover the body from skull base to proximal thighs $[4,5]$. Twenty-one case reports of solitary brain metastases from prostate cancer were found in the literature, summarised in Table 1 [6-21], adapted from Barakat et al. (2016) [17].

\section{Case presentation}

A 62-year old male patient had a robot-assisted laparoscopic prostatectomy in August 2014 for a Gleason $4+$ 3 multifocal adenocarcinoma with tertiary grade 5 disease and extraprostatic extension (pT3aNOMx). The 
Table 1 Literature summary of intracranial metastatic prostate cancer case reports without systemic disease

\begin{tabular}{|c|c|c|c|c|c|c|c|}
\hline \multirow{3}{*}{$\begin{array}{l}\frac{\text { Literature sum }}{\text { Study (author, year) }} \\
\text { Rao et al., } 1982[6]\end{array}$} & \multirow{2}{*}{\multicolumn{2}{|c|}{ Age Initial presentation }} & \multirow[b]{2}{*}{$\begin{array}{l}\text { Swithout systemic } \\
\text { metastases of brain } \\
\text { metast }\end{array}$} & & \multirow{3}{*}{$\begin{array}{l}\begin{array}{l}\text { Functional status post- } \\
\text { operatively }\end{array} \\
\text { Loss of vision in left eye. }\end{array}$} & \multirow{3}{*}{$\begin{array}{l}\text { Disease and survival outcomes } \\
\text { Transurethral resection of the prostate, } \\
2 \text { years post operatively, alive and well } 6 \\
\text { years from diagnosis. }\end{array}$} \\
\hline & & & & $\begin{array}{l}\text { Description, including size \& } \\
\text { location, of brain metastases }\end{array}$ & $\begin{array}{l}\text { Treatment of brain } \\
\text { metastases }\end{array}$ & & \\
\hline & 75 & Headache, palsies of left cranial nerves II, III, V and VI. & 1 & $\begin{array}{l}\text { Size not reported, located in the } \\
\text { left cavernous sinus, superior } \\
\text { orbital fissure and posterior orbit. }\end{array}$ & Craniotomy and resection. & & \\
\hline Lynes et al., 1986 [7] & 65 & $\begin{array}{l}\text { Headaches, memory loss, cerebellar ataxia, } \\
\text { papilloedema, following transurethral resection of the } \\
\text { prostate } 3 \text { months earlier, diffusely firm } 15 \mathrm{~g} \text { prostate } \\
\text { with hard } 1 \mathrm{~cm} \text { nodule at the left base. }\end{array}$ & 1 & $\begin{array}{l}5 \mathrm{~cm} \text { diameter non enhancing right } \\
\text { cerebellar lesion, with obstructive } \\
\text { hydrocephalus. }\end{array}$ & $\begin{array}{l}\text { Craniotomy and resection, } \\
\text { followed by external beam } \\
\text { irradiation to the whole } \\
\text { brain and posterior fossa. }\end{array}$ & $\begin{array}{l}\text { Almost total resolution } \\
\text { of neurological } \\
\text { symptoms. }\end{array}$ & $\begin{array}{l}\text { Alive and well } 60 \text { weeks post- } \\
\text { operatively, with no neurological, } \\
\text { urological, or bone symptoms. }\end{array}$ \\
\hline $\begin{array}{l}\text { Kasabian et al., } 1992 \\
{[8]}\end{array}$ & 75 & $\begin{array}{l}\text { Gait disturbance, dizziness, personality change, left } \\
\text { homonymous hemianopsia, symmetrically enlarged } \\
\text { prostate without nodules and no intraluminal mass. }\end{array}$ & 1 & $\begin{array}{l}\text { Enhancing lesion in the right } \\
\text { occipital lobe, size not reported. }\end{array}$ & $\begin{array}{l}\text { Craniotomy and resection } \\
\text { with post-operative WBRT. }\end{array}$ & Resolution of symptoms. & $\begin{array}{l}\text { Presented with widespread metastates } \\
13 \text { months post-operatively, treated } \\
\text { with diethylstilbestrol diphosphate and } \\
\text { radiation. Clinically stable } 2 \text { years and } 9 \\
\text { months after craniotomy. }\end{array}$ \\
\hline $\begin{array}{l}\text { Kunkler et al., } 1993 \\
\text { [9] }\end{array}$ & 71 & Not reported. & 1 & Right parietal lobe. & Craniotomy and resection. & $\begin{array}{l}\text { Functioning normally } \\
\text { except for some residual } \\
\text { spasticity in the left leg. }\end{array}$ & $\begin{array}{l}\text { Recurrent tumour treated with surgery } \\
\text { at } 4 \text { months. Alive } 2 \text { years post- } \\
\text { operatively. }\end{array}$ \\
\hline $\begin{array}{l}\text { Gupta et al., } 1994 \\
\text { [10] }\end{array}$ & 55 & $\begin{array}{l}\text { Headache and tendency to "lean to the right", } 1 \text { year } \\
\text { after radical prostatectomy and external beam } \\
\text { radiation. }\end{array}$ & 1 & $\begin{array}{l}\text { Enhancing mass on MRI, } 2 \mathrm{~cm} \times \\
3 \mathrm{~cm} \text {, left pons/left cerebral } \\
\text { peduncle. }\end{array}$ & $\begin{array}{l}\text { Stereotactic biopsy and } \\
\text { palliative external beam } \\
\text { radiation to whole brain } \\
\text { and brain stem. }\end{array}$ & $\begin{array}{l}\text { No residual neurological } \\
\text { symptoms, but non- } \\
\text { specific gastrointestinal } \\
\text { symptoms. }\end{array}$ & $\begin{array}{l}\text { Alive } 2 \text { months post-external beam } \\
\text { radiation therapy. }\end{array}$ \\
\hline $\begin{array}{l}\text { Sutton et al., } 1996 \\
\text { [11] }\end{array}$ & 62 & $\begin{array}{l}\text { Nausea, vomiting, anorexia, 30lb weight loss over } 2 \\
\text { months, left sided weakness, chronic rhythmic } \\
\text { shaking in left upper arm, mild ataxia. On exam, } \\
\text { tremor in left upper arm and weakness in left arm } \\
\text { and leg, mildly enlarged but smooth prostate. }\end{array}$ & 1 & $\begin{array}{l}3 \times 4 \mathrm{~cm} \text { right posterior fossa mass, } \\
\text { in the right pons and cerebellar } \\
\text { peduncle. }\end{array}$ & $\begin{array}{l}\text { Biopsy, radiotherapy, } \\
\text { intravenous steroids. }\end{array}$ & $\begin{array}{l}\text { Improved neurological } \\
\text { function. }\end{array}$ & $\begin{array}{l}\text { Alive with improved symptoms } 4 \text { week } \\
\text { later. Long term outcome not reported. }\end{array}$ \\
\hline $\begin{array}{l}\text { McCutcheon et al., } \\
1999[12]\end{array}$ & 60 & $\begin{array}{l}\text { Stage } \mathrm{C} 1 \text { prostate adenocarcinoma, treated with local } \\
\text { radiotherapy. }\end{array}$ & $\geq 4$ & Not reported. & WBRT. & Not reported. & $\begin{array}{l}\text { Survived } 11 \text { months after detection of } \\
\text { brain metastases. }\end{array}$ \\
\hline $\begin{array}{l}\text { McCutcheon et al., } \\
1999[12]\end{array}$ & 63 & $\begin{array}{l}\text { Stage A2 prostate adenocarcinoma, treated with } \\
\text { prostatectomy and local radiotherapy. }\end{array}$ & 3 & Not reported. & WBRT. & Not reported. & $\begin{array}{l}\text { Survived } 1 \text { month after detection of } \\
\text { brain metastases. }\end{array}$ \\
\hline $\begin{array}{l}\text { McCutcheon et al., } \\
1999 \text { [12] }\end{array}$ & 64 & $\begin{array}{l}\text { Stage A2 prostate adenocarcinoma, treated with } \\
\text { prostatectomy. }\end{array}$ & 1 & Not reported. & WBRT. & Not reported. & $\begin{array}{l}\text { Survived } 2 \text { months after detection of } \\
\text { brain metastasis. }\end{array}$ \\
\hline $\begin{array}{l}\text { McCutcheon et al., } \\
1999[12]\end{array}$ & 72 & $\begin{array}{l}\text { Stage C2 prostate adenocarcinoma, treated with } \\
\text { prostatectomy and bilateral orchiectomy. }\end{array}$ & $\geq 4$ & Not reported. & WBRT. & Not reported. & $\begin{array}{l}\text { Survived } 2 \text { months after detection of } \\
\text { brain metastases. }\end{array}$ \\
\hline $\begin{array}{l}\text { McCutcheon et al., } \\
1999[12]\end{array}$ & 77 & $\begin{array}{l}\text { Stage A1 prostate adenocarcinoma, treated with local } \\
\text { radiotherapy and cytotoxic chemotherapy. }\end{array}$ & 1 & Not reported. & $\begin{array}{l}\text { Surgery and post-operative } \\
\text { WBRT. }\end{array}$ & Not reported. & $\begin{array}{l}\text { Survived } 2 \text { months after detection of } \\
\text { brain metastases. }\end{array}$ \\
\hline $\begin{array}{l}\text { McCutcheon et al., } \\
1999[12]\end{array}$ & 80 & $\begin{array}{l}\text { Stage } \mathrm{C} 1 \text { prostate adenocarcinoma, treated with } \\
\text { prostatectomy and local radiotherapy. }\end{array}$ & 2 & Not reported. & WBRT. & Not reported. & $\begin{array}{l}\text { Survived } 6 \text { months after detection of } \\
\text { brain metastases. }\end{array}$ \\
\hline $\begin{array}{l}\text { Salvati et al., } 2005 \\
\text { [13] }\end{array}$ & 68 & Not reported. & 1 & Temporal lobe. & $\begin{array}{l}\text { Craniotomy and resection, } \\
\text { and WBRT. }\end{array}$ & Not reported. & Alive 20 months post-operatively. \\
\hline $\begin{array}{l}\text { Sweets et al, } 2009 \\
\text { [14] }\end{array}$ & 48 & $\begin{array}{l}\text { Gleason } 4+5=9 \text {, treated with neoadjuvant } \\
\text { chemotherapy, radical prostatectomy, and } \\
\text { radiotherapy. Grand mal seizure four years after } \\
\text { initial diagnosis. }\end{array}$ & 1 & $\begin{array}{l}2 \times 1 \times 1 \mathrm{~cm} \text { enhancing lesion in left } \\
\text { parietal lobe. }\end{array}$ & $\begin{array}{l}\text { Craniotomy and resection, } \\
\text { with local brachytherapy } \\
\text { (125I seeds). }\end{array}$ & $\begin{array}{l}\text { Minor cognitive } \\
\text { sequelae, but able to } \\
\text { work and perform daily } \\
\text { activities without } \\
\text { assistance. }\end{array}$ & $\begin{array}{l}\text { Alive } 5 \text { years post-resection (PSA } \\
<0.1 \mathrm{ng} / \mathrm{dL} \text { ). }\end{array}$ \\
\hline $\begin{array}{l}\text { Mithal et al., } 2014 \\
\text { [15] }\end{array}$ & 69 & 6 week history of left-sided weakness. & 1 & $\begin{array}{l}3.4 \mathrm{~cm} \text { enhancing lesion in right } \\
\text { parietal lobe. }\end{array}$ & $\begin{array}{l}\text { Craniotomy and resection } \\
\text { followed by WBRT. }\end{array}$ & Not reported. & $\begin{array}{l}\text { Alive } 3.5 \text { years post-operatively, with no } \\
\text { evidence of metastatic disease. }\end{array}$ \\
\hline Craig et al., 2015 [16] & 79 & $\begin{array}{l}\text { Gleason } 6 \text { T2B, treated with radiotherapy and } \\
\text { adjuvant hormonal therapy. Asymptomatic } \\
\text { biochemical recurrence } 9 \text { years post-radiotherapy. }\end{array}$ & 1 & $\begin{array}{l}3.5 \mathrm{~cm} \text { right frontal intra-axial } \\
\text { enhancing lesion. }\end{array}$ & Craniotomy and resection. & $\begin{array}{l}\text { No post-operative } \\
\text { complications; no } \\
\text { neurocognitive problems, } \\
\text { headaches, or seizures. }\end{array}$ & $\begin{array}{l}\text { Recurrence after } 8 \text { months, survived } 19 \\
\text { months. }\end{array}$ \\
\hline $\begin{array}{l}\text { Barakat et al., } 2016 \\
\text { [17] }\end{array}$ & 67 & $\begin{array}{l}\text { Gleason } 4+4=8 \text { T3a treated with radiothC19:C20erapy. } \\
\text { Dizziness, mild dysphagia and imbalance, } 6 \text { years } \\
\text { after initial presentation. }\end{array}$ & 1 & $\begin{array}{l}\text { Multi-lobulated intra-axial lesion } \\
\text { in the left frontal lobe. }\end{array}$ & $\begin{array}{l}\text { Craniotomy and resection } \\
\text { followed by stereotactic } \\
\text { radiotherapy, ADT. }\end{array}$ & $\begin{array}{l}\text { Complication-free } \\
\text { postoperative recovery } \\
\text { with no neurological } \\
\text { deficits. }\end{array}$ & $\begin{array}{l}\text { PSA undetectable and no evidence of } \\
\text { recurrence at } 17 \text { months post } \\
\text { radiotherapy. }\end{array}$ \\
\hline $\begin{array}{l}\text { Campagna et al., } \\
2018[18]\end{array}$ & 77 & $\begin{array}{l}\text { Unwitnessed fall, background of falls, memory } \\
\text { deficits, weight loss. }\end{array}$ & 1 & $\begin{array}{l}3 \mathrm{~cm} \text { bilobed lesion in left frontal } \\
\text { lobe. }\end{array}$ & $\begin{array}{l}\text { craniotomy and resection } \\
\text { followed by stereotactic } \\
\text { radiotherapy and ADT. }\end{array}$ & Not reported. & $\begin{array}{l}\text { Follow-up imaging demonstrates } \\
\text { development of suspected bone } \\
\text { metastases, long term outcome not } \\
\text { reported. }\end{array}$ \\
\hline Yin et al., 2019 [19] & 66 & $\begin{array}{l}\text { Rise in PSA to } 7.1 \mathrm{ng} / \mathrm{mL}, 13 \text { after radical } \\
\text { prostatectomy for Gleason } 4+3=7 \text { prostate } \\
\text { adenocarcinoma. }\end{array}$ & 2 & $\begin{array}{l}4.5 \times 6 \times 6.5 \mathrm{~cm} \text { cystic lesion in the } \\
\text { right temporal lobe, } 11 \mathrm{~mm} \text { lesion } \\
\text { in the left occipital lobe. }\end{array}$ & $\begin{array}{l}\text { craniotomy and resection } \\
\text { of right temporal lobe } \\
\text { lesion, stereotactic } \\
\text { radiotherapy for left } \\
\text { occipital lobe lesion. }\end{array}$ & Not reported. & Alive and well 3 years post-operatively. \\
\hline $\begin{array}{l}\text { Ishizaki et al., } 2019 \\
\text { [20] }\end{array}$ & 63 & $\begin{array}{l}\text { Gleason } 5+5 \text { treated with ADT, chemotherapy, } \\
\text { bracytherapy and radiotherapy. Presented with } \\
\text { dizziness } 2 \text { years } 8 \text { months after initial presentation. }\end{array}$ & 1 & $\begin{array}{l}\text { Multi-lobulated, intra-axial lesion } \\
\text { in the right cerebellar hemisphere. }\end{array}$ & $\begin{array}{l}\text { craniotomy and resection } \\
\text { followed by WBRT. }\end{array}$ & Not reported. & $\begin{array}{l}\text { PSA undetectable and no evidence of } \\
\text { recurrent disease at } 23 \text { months. }\end{array}$ \\
\hline Hafiz et al., 2019 [21] & 59 & $\begin{array}{l}\text { Acute headache secondary to a fall. Background of } \\
\text { decreased vision, lack of concentration and difficulty } \\
\text { walking for one month. Also, decreased urinary } \\
\text { frequency, and poor urinary stream for } 6 \text { months. On } \\
\text { exam, left-sided homonymous hemianopia, tandem } \\
\text { gait, enlarged prostate with no nodularity. }\end{array}$ & 1 & $\begin{array}{l}\text { lesion in the right posterior } \\
\text { parietal-occipital region. }\end{array}$ & $\begin{array}{l}\text { Craniotomy and resection } \\
\text { followed by WBRT. }\end{array}$ & $\begin{array}{l}\text { Recovered well } \\
\text { postoperatively. }\end{array}$ & $\begin{array}{l}\text { PSA } 3.31 \mathrm{ng} / \mathrm{ml} \text { after one year with no } \\
\text { evidence of recurrence or systemic } \\
\text { disease. }\end{array}$ \\
\hline
\end{tabular}

pre-operative PSA was $5.3 \mu \mathrm{g} / \mathrm{L}$ and the post-operative PSA was unchanged at $5.63 \mu \mathrm{g} / \mathrm{L}$, despite negative surgical margins (Fig. 1). The PSA, 6 months postoperatively, had increased to $10.06 \mu \mathrm{g} / \mathrm{L}$. Pelvic MRI showed no local recurrence or residual prostatic tissue and a bone scan was also negative. Androgen deprivation therapy (ADT) was commenced with a subsequent fall in PSA to $<0.02 \mu \mathrm{g} / \mathrm{L}$, but it was discontinued after a year due to side effects.

Serum PSA tests were undertaken regularly (Fig. 1). 4.5 years post-operatively, the PSA increased to $2.33 \mu \mathrm{g} /$
L and staging CT and whole-body bone scintigram showed no evidence of metastatic disease.

Five years after prostatectomy, the PSA reached 10.6 $\mu \mathrm{g} / \mathrm{L}$, and the patient underwent a $\left[{ }^{68} \mathrm{Ga}\right] \mathrm{Ga}-\mathrm{THP}-\mathrm{PSMA}$ PET/CT using a cold kit PSMA formulation [22-25]. Sixty minutes after intravenous injection of $204 \mathrm{MBq}$ of tracer a $\left[{ }^{68} \mathrm{Ga}\right] \mathrm{Ga}-\mathrm{THP}-\mathrm{PSMA}$ PET/CT was acquired from proximal thighs to skull base on a GE Discovery 690 PET-CT scanner (GE Healthcare, Chicago, USA) according to current guidelines [5] (4 min per bed position with $23 \%$ overlap and axial field of view of $16 \mathrm{~cm}$ ). A 


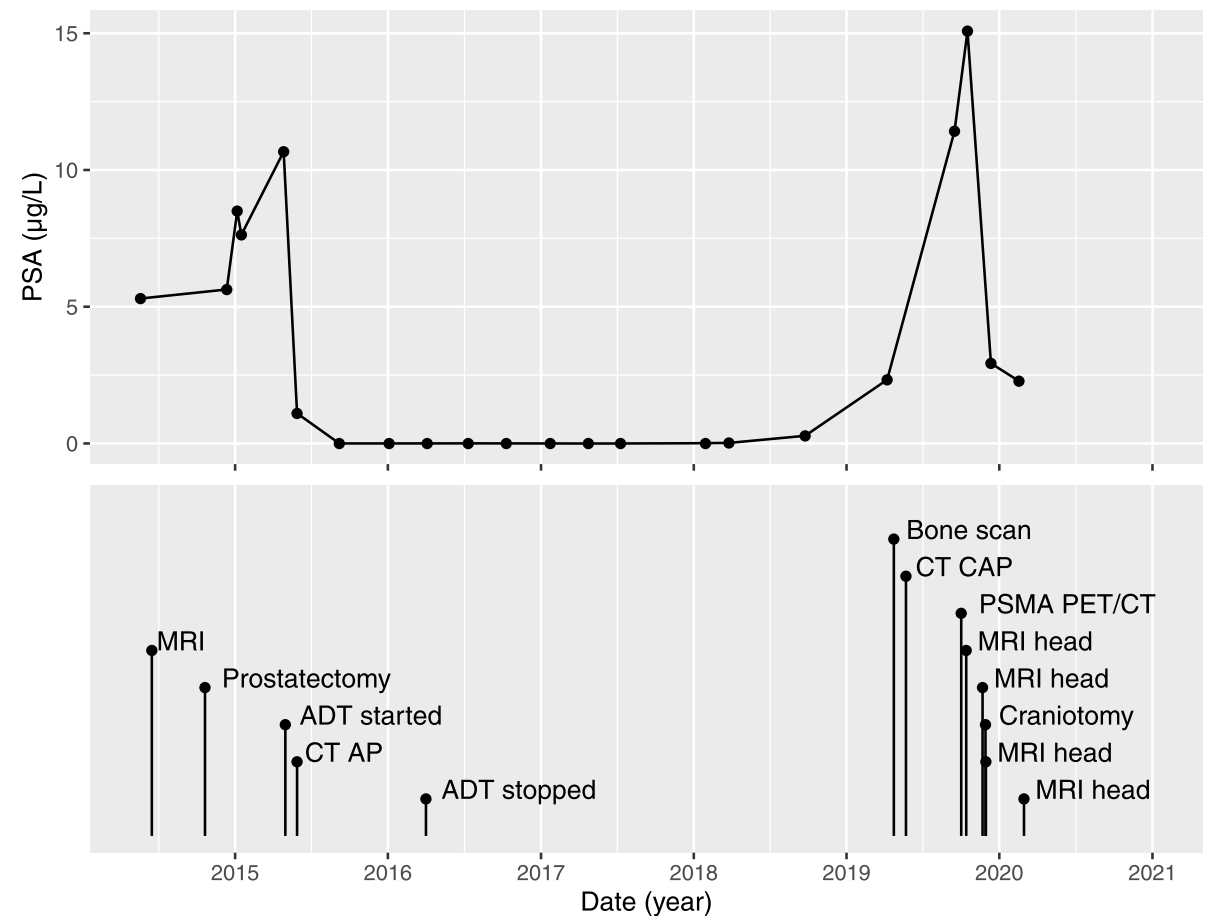

Fig. 1 Serum PSA, with procedures, over time. Top: serum PSA ( $\mu \mathrm{g} / \mathrm{L}$ ) over time (values of $<0.02 \mu \mathrm{g} / \mathrm{L}$ are plotted as $0 \mu \mathrm{g} / \mathrm{L}$ ); bottom: procedures over time

low-dose unenhanced CT scan $(120 \mathrm{kVp}, 0.5 \mathrm{~s}$ rotation time, $3.75 \mathrm{~mm}$ slices, Noise Index 45, 10-180 mA) was performed for attenuation correction and localization purposes. PET reconstructions included corrections for radiotracer decay, attenuation, modeled scatter, randoms and dead-time, both for time-of-flight (TOF ordered subset expectation maximisation with 24 subsets and 2 iterations) and scatter-limit correction series. The PET/ CT showed increased focal uptake in the right midcranial fossa, with no focal uptake in the rest of the body. The differential considered at this point was a meningioma, glioma or a prostate metastasis, all known to express PSMA [26-29]. The patient had no neurological symptoms at the time of presentation.

A subsequent contrast-enhanced MRI head showed a well-demarcated enhancing dural-based lesion in the floor of the right middle cranial fossa, projecting into the right temporal lobe, with surrounding T2 hyperintense changes in the right temporal lobe, believed to be extra-axial on MRI. The lesion was thought initially to represent a meningioma, both on the $\left[{ }^{68} \mathrm{Ga}\right] \mathrm{Ga}-\mathrm{THP}-$ PSMA PET/CT $\left(\mathrm{SUV}_{\max } \mathrm{TOF}=6.2\right)$ and contrastenhanced MRI, although the PET/CT had raised the suspicion of a prostate cancer metastasis given its unusually intense uptake (Fig. 2).

As uncertainty remained between the two possible diagnoses (meningioma or prostate cancer metastasis) in the neuro-oncology multidisciplinary team meeting, the patient was referred for a neurosurgical opinion, which advised the lesion's surgical resection and dexamethasone $4 \mathrm{mg}$ bd, to reduce surrounding oedema. A second MRI head, performed 1 month later for pre-surgical planning, confirmed a $23 \times 18 \mathrm{~mm}$ solitary tumour with surrounding oedema in the anterior part of the right inferior temporal gyrus. The tumour contained heterogeneous low and high areas of T2 signal, patchy heterogeneous contrast enhancement and dural extension to the brain surface inferiorly. The second MRI suggested that the lesion was intra-axial. The contrast-enhanced post-operative MRI head showed complete resection of the tumour with a reduction in serum PSA to $2.93 \mu \mathrm{g} / \mathrm{L}$. The histopathology report confirmed an intra-axial right temporal lobe metastatic prostatic adenocarcinoma with dural extension and intense PSA and PSAP staining. Three months after neurosurgery the patient had recovered well with only mild neurological deficit (left foot drop). Surveillance MRI showed no intracranial mass or abnormal contrast enhancement to indicate residual or recurrent tumour and only expected post-operative encephalomalacia in the anterior inferior part of the right temporal lobe. The serum PSA remained elevated $(2.28 \mu \mathrm{g} / \mathrm{l})$. Currently, the patient is followed up with 3monthly MRIs and PSA monitoring. ADT has not been restarted. Although the post-operative MRI head showed complete resection, the fact that histopathology documented dural involvement could explain the elevated 


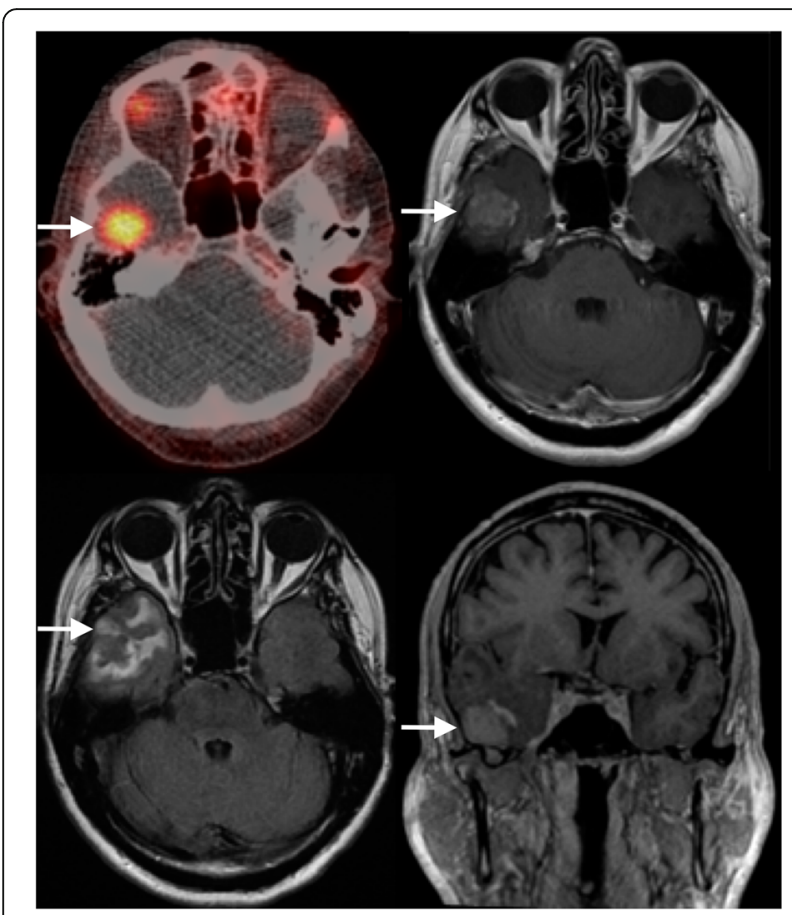

Fig. 2 Selected images through the skull base from the $[\wedge 68 \mathrm{Ga}] \mathrm{Ga}-$ THP-PSMA PET/CT and subsequent MRI. Top left: axial fused PET/CT image revealing focal uptake in the right middle cranial fossa; bottom left: axial FLAIR MRI showing white matter oedema in the right temporal lobe; top (axial) and bottom (coronal) right: postcontrast enhanced T1-weighted MR images demonstrating an enhancing lesion in the floor of the right middle cranial fossa in close contact with the dura mater

PSA after surgery and potential presence of residual microscopic meningeal disease. The patient is currently asymptomatic, but he will undergo further PSMA PET/ $\mathrm{CT}$ if the PSA continues to rise.

\section{Discussion}

This is the first case report of a solitary brain oligometastasis in a neurologically intact prostate cancer patient with no other systemic disease using $\left[{ }^{68} \mathrm{Ga}\right] \mathrm{Ga}$-THPPSMA PET/CT and only the second one using a PSMAbased radiopharmaceutical [19]. Current guidelines for $\left[{ }^{68} \mathrm{Ga}\right] \mathrm{Ga}$-PSMA PET in prostate cancer patients recommend skull base to proximal thighs coverage [5], which may result in brain or skull metastases located more cranially remaining undetected. In our case, the solitary brain metastasis was only seen on the most cranial PET slices, and, left undiagnosed, would have further increased in size until neurological symptoms became apparent, resulting in delayed treatment and increased morbidity. Our report illustrates the need to consider the presence of metastatic disease outside the conventional locations of prostate cancer in patients with persistent or rising PSA and negative conventional imaging.
The other case report, from Yin et al. (2019), describes a clinical situation remarkably similar to ours [19]. Both report asymptomatic patients who presented with a rise in serum PSA, after having previously undergone radical prostatectomy for Gleason grade $4+3=7$ prostate adenocarcinoma. Both patients were subsequently found to have a cerebral metastasis in the right temporal lobe, although the patient in Yin et al. (2019) also had a smaller metastasis in the left occipital lobe.

The use of $\left[{ }^{68} \mathrm{Ga}\right] \mathrm{Ga}$-PSMA PET/CT played a crucial role in the management of these patients and led to detection and treatment of their disease. A recent study [30] found that in patients with biochemical recurrence and in the absence of radiological evidence of metastatic disease on CT or bone scan $\left[{ }^{68} \mathrm{Ga}\right] \mathrm{Ga}$-PSMA PET/CT may lead to a change in management for up to $96 \%$ of patients. Although this study is limited by a small number (33) of patients, the results are nonetheless impressive. For our patient, the $\left[{ }^{68} \mathrm{Ga}\right] \mathrm{Ga}$-THP-PSMA PET/CT resulted in a major change in management (surgical resection) and prevented a delayed presentation with neurological symptoms, systemic (including further intracranial) metastatic disease, emergency neurosurgery and increased morbidity.

\section{Conclusion}

This is the first documented case of a solitary cerebral metastasis from prostate cancer in the absence of systemic disease being diagnosed using $\left[{ }^{68} \mathrm{Ga}\right] \mathrm{Ga}$-THPPSMA PET/CT. It demonstrates the usefulness of this relatively new imaging modality in the investigation and staging of prostate cancer, as well as the importance of ensuring comprehensive, vertex-to-thighs, coverage when performing a $\left[{ }^{68} \mathrm{Ga}\right] \mathrm{Ga}$-PSMA PET study in patients with high suspicion of prostate cancer metastases.

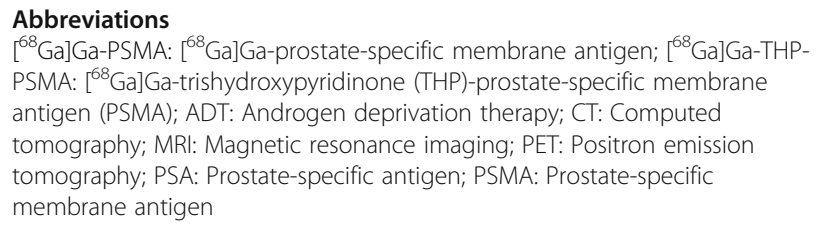

\section{Acknowledgements}

The authors would like to thank departmental staff for their assistance with tracer production, PET/CT acquisition and appointment scheduling.

\section{Authors' contributions}

MIR performed the literature review, produced Fig. 1, was a major contributor to retrieving patient information from records and was the primary contributor to writing the manuscript. NB was a contributor to retrieving patient information from records and a major contributor to writing the case presentation section, particularly with regards to the PSMA PET/CT scan. IAM was a major contributor to retrieving patient information from records, produced Fig. 2 and was a major contributor to the writing of the manuscript. YLR was a major contributor to retrieving patient information from records and a major contributor to the writing of the manuscript. All authors read and approved the final manuscript. 


\section{Funding}

This work was supported by the Cancer Research UK Cambridge Centre [A25177].

\section{Availability of data and materials}

All data generated or analysed during this study are included in this published article.

\section{Ethics approval and consent to participate}

Not applicable. Not classed as research under the UK Health Research Authority's regulations on human research.

\section{Consent for publication}

Written informed consent was obtained from the patient for publication of this case report and accompanying images.

\section{Competing interests}

The authors declare that they have no competing interests.

\section{Author details}

'School of Clinical Medicine, University of Cambridge, Cambridge Biomedical Campus, Hills Road, Cambridge CB2 0QQ, UK. ²Department of Nuclear Medicine, Cambridge University Hospitals NHS Foundation Trust, Cambridge Biomedical Campus, Hills Road, Cambridge CB2 0QQ, UK. ${ }^{3}$ Department of Radiology, University of Cambridge, Cambridge Biomedical Campus, Hills Road, Cambridge CB2 OQQ, UK. ${ }^{4}$ Cancer Research UK Cambridge Centre, Cambridge Biomedical Campus, Hills Road, Cambridge CB2 OQQ, UK. ${ }^{5}$ Department of Oncology, Cambridge University Hospitals NHS Foundation Trust, Cambridge Biomedical Campus, Hills Road, Cambridge CB2 OQQ, UK.

Received: 22 July 2020 Accepted: 10 September 2020

Published online: 22 September 2020

\section{References}

1. Tremont-Lukats IW, Bobustuc G, Lagos GK, Lolas K, Kyritsis AP, Puduvalli VK. Brain metastasis from prostate carcinoma: The M. D. Anderson Cancer Center experience. Cancer. 2003;98:363-8.

2. Guo Y, Mao S, Zhang A, Wang R, Zhang Z, Zhang J, et al. Prognostic significance of young age and non-bone metastasis at diagnosis in patients with metastatic prostate cancer: a SEER population-based data analysis. J Cancer. 2019;10:556-67.

3. Shou J, Zhang Q, Wang S, Zhang D. The prognosis of different distant metastases pattern in prostate cancer: A population based retrospective study. Prostate. 2018;78:491-7.

4. Gillessen S, Attard G, Beer TM, Beltran H, Bjartell A, Bossi A, et al Management of patients with advanced prostate cancer: report of the advanced prostate cancer consensus conference 2019. Eur Urol. 2020;77: 508-47.

5. Fendler WP, Eiber M, Beheshti M, Bomanji J, Ceci F, Cho S, et al. ${ }^{68} \mathrm{Ga}-\mathrm{PSMA}$ PET/CT: Joint EANM and SNMMI procedure guideline for prostate cancer imaging: version 1.0. Eur J Nucl Med Mol Imaging. 2017;44:1014-24.

6. Rao KG. Carcinoma of prostate presenting as intracranial tumor with multiple cranial nerve palsies. Urology. 1982;19:433-5.

7. Lynes WL, Bostwick DG, Freiha FS, Stamey TA. Parenchymal brain metastases from adenocarcinoma of prostate. Urology. 1986;28:280-7.

8. Kasabian NG, Previte SR, Kaloustian HD, Ganem EJ. Adenocarcinoma of the prostate presenting initially as an intracerebral tumor. Cancer. 1992; 70:2149-51.

9. Kunkler RB, Cooksey G, Millac P. Carcinoma of the prostate presenting with a cerebral metastasis. Br J Urol. 1993;71:103-4.

10. Gupta A, Baidas S, Cumberlin RK. Brain stem metastasis as the only site of spread in prostate carcinoma. A case report. Cancer. 1994;74:2516-9.

11. Sutton MA, Watkins HL, Green LK, Kadmon D. Intracranial metastases as the first manifestation of prostate cancer. Urology. 1996;48:789-93.

12. McCutcheon IE, Eng DY, Logothetis CJ. Brain metastasis from prostate carcinoma: antemortem recognition and outcome after treatment. Cancer. 1999:86:2301-11

13. Salvati M, Frati A, Russo N, Brogna C, Piccirilli M, D'Andrea G, et al. Brain metastasis from prostate cancer. Report of 13 cases and critical analysis of the literature. J Exp Clin Cancer Res. 2005;24:203-7.
14. Sweets T, Bracken RB, Geisler EJ, Warnick R. Intracranial treatment for solitary prostatic adenocarcinoma brain metastasis is curative. Urology. 2009;73:681.e7-9.

15. Mithal $\mathrm{P}$, Gong $Y$, Sirkis $H$, Aronowitz JN. A brain lesion as the sole metastasis of prostate cancer. Journal of Clinical Urology. 2016;9:348-50.

16. Craig J, Woulfe J, Sinclair J, Malone S. Isolated brain metastases as first site of recurrence in prostate cancer: case report and review of the literature. Curr Oncol. 2015;22:e493-7.

17. Barakat T, Agarwal A, McDonald R, Ganesh V, Vuong S, Borean M, et al. Solitary brain metastasis from prostate cancer: a case report. Ann Palliat Med. 2016:5:227-32.

18. Campagna JP, Feia K. Isolated brain metastasis of prostate carcinoma in the setting of normal prostate specific antigen. Urol Case Rep. 2018;21:67-9.

19. Yin C, Ho B, Chan L, Emmett L. Asymptomatic prostate cancer brain metastases on 68Ga-PSMA PET/CT. Clin Nucl Med. 2019:44:e382-4.

20. Ishizaki F, Maruyama R, Yamana K, Kasahara T, Nishiyama T, Tomita Y. Solitary brain metastasis from prostate cancer after multi modality treatment: A case report. Urol Case Rep. 2019;24:100879.

21. Hafiz A, Karim MU, Qureshi BM, Jabbar AA, Ahmad Z. Solitary brain metastasis: a rare initial presentation of prostate carcinoma. Cureus. 2019;11:e4804.

22. Derlin T, Schmuck S, Juhl C, Teichert S, Zörgiebel J, Wester HJ, et al. Imaging characteristics and first experience of $\left[{ }^{68} \mathrm{Ga}\right]$ THP-PSMA, a novel probe for rapid kit-based Ga-68 labeling and PET imaging: comparative analysis with $\left[{ }^{68} \mathrm{Ga}\right]$ PSMA I\&T. Mol Imaging Biol. 2018;20:650-8.

23. Derlin T, Schmuck S, Juhl C, Zörgiebel J, Schneefeld SM, ACA W, et al. PSAstratified detection rates for $\left[{ }^{68} \mathrm{Ga}\right]$ THP-PSMA, a novel probe for rapid kitbased ${ }^{68} \mathrm{Ga}$-labeling and PET imaging, in patients with biochemical recurrence after primary therapy for prostate cancer. Eur J Nucl Med Mol Imaging. 2018;45:913-22

24. Hofman MS, Eu P, Jackson P, Hong E, Binns D, Iravani A, et al. Cold kit for prostate-specific membrane antigen (PSMA) PET imaging: phase 1 study of ${ }^{68} \mathrm{Ga}$-Tris(Hydroxypyridinone)-PSMA PET/CT in patients with prostate cancer. J Nucl Med. 2018;59:625-31.

25. Young JD, Abbate V, Imberti C, Meszaros LK, Ma MT, Terry SYA, et al. ${ }^{68} \mathrm{Ga}$ THP-PSMA: a PET imaging agent for prostate cancer offering rapid, roomtemperature, 1-step kit-based radiolabeling. J Nucl Med. 2017;58:1270-7.

26. Bertagna F, Albano D, Cerudelli E, Gazzilli M, Giubbini R, Treglia G. Potential of radiolabelled PSMA PET/CT or PET/MRI diagnostic procedures in gliomas/ glioblastomas [published online ahead of print, 2019 Oct 16]. Curr Radiopharm. https://doi.org/10.2174/1874471012666191017093721.

27. Haemels M, Jentjens S, Cleeren F, Sciot R, Lambert J, Van Laere K, et al. All that glitters is not prostate cancer: incidental finding of PSMA-avid meningioma. Hell J Nucl Med. 2020;23:79-80.

28. Jain TK, Jois AG, Kumar VS, Singh SK, Kumar R, Mittal BR. Incidental detection of tracer avidity in meningioma in ${ }^{68} \mathrm{Ga}$-PSMA PET/CT during initial staging for prostate cancer. Rev Esp Med Nucl Imagen Mol. 2017; 36:133-4.

29. Bilgin R, Ergül N, Çermik TF. Incidental meningioma mimicking metastasis of prostate adenocarcinoma in 68Ga-labeled PSMA ligand PET/CT. Clin Nucl Med. 2016;41:956-8.

30. Keane F, Ged Y, Greally M, Maher MA, O'Malley K, McCaffrey J. Prostatespecific membrane antigen (PSMA) PET-CT imaging in the investigation and management of biochemical recurrence in prostate cancer. J Clin Oncol. 2018;36(Suppl 6):208.

\section{Publisher's Note}

Springer Nature remains neutral with regard to jurisdictional claims in published maps and institutional affiliations. 